reduction of capital from $£ 95,000,000$ to $£ 89,565,859$, the petition being opposed by a committee representing more than 13,000 holders of Deferred shares. In evidence, Sir Albert Wyon, chartered accountant, agreed that the company is spending large sums of money on research which have yielded valuable returns. These returns appear in the accounts in the shape of increased revenue. In this connexion, it is of interest to recall that, when this great combine was formed, NATURE, in a leading article (January 29,1927, p. 149), stressed its importance from the point of view of scientific research: "Of special interest, fully recognised by the promoters of the trust, is the question whether it will be possible to improve methods and results in scientific research. The record of the constituent companies in this respect is creditable enough, and the work they accomplished during the War earned the gratitude of the nation. But combination must tend towards greater economy and greater efficiency."

\section{Cornish Engines Preservation Fund}

CoRnWaLl occupies a unique place in the industrial history of Great Britain, owing to its contributions to the advancement of mining and the development of the steam engine. The natural pride Cornishmen take in the achievements of the inventors and engineers of the county has found expression in various ways, and a scheme has now been set on foot for preserving, before it is too late, some of the few remaining Cornish beam engines. At a meeting held at Murdock House, Redruth, on October 15, a committee was formed to further the scheme, and an appeal has been made for funds for the purchase of a winding engine at Levant Mine, designed nearly a century ago by Francis Mitchell, and probably constructed at Copperhouse Foundry, Hayle. The engine, which is of the beam type, has a cylinder $24 \mathrm{in}$. in diameter with a stroke of $4 \mathrm{ft}$. As the mine, after a life of 110 years, has been closed down, the engine can be purchased at scrap value and arrangement can be made for its preservation in situ with a right of way to it, the total sum required for the purchase of the engine, repairs to the engine house and for maintenance being estimated at $£ 300$. The honorary secretaries to the committee are $\mathrm{Mr}$. W. T. Hooper, of Falmouth Observatory, and Mr. W. A. Michell, Couch Lane, Redruth, while the honorary treasurer is Mr. H. Michell, of Barclays Bank, Falmouth, to whom subscriptions should be sent.

\section{Quarterly List of Scientific Books}

The Association of Special Libraries and Information Bureaux, 16 Russell Square, London, W.C.1, has recently issued a book list which is the first of a series of quarterly recommendations of recently published scientific and technical books $(10 s .6 d$. a year for non-members). The main object of the list is to provide public and other libraries with a selected list of recent scientific and technical books, and the list has been compiled with the assistance of more than sixty specialist organisations which are able to assess the relative merits of new publications in their own fields. Only books in the English language, and, with few exceptions, those published in the last six months, have been included. No attempt has been made to introduce detailed classification, the books being listed under broad main headings, such as General Science and Technology; Chemistry and Chemical Technology ; Physics ; Metallurgy ; Medicine, Public Health and Nutrition; Communications and Transport, etc. The books are further sub-divided into those suitable for general readers, books of an intermediate character or suitable as textbooks for students, advanced or highly technical books, and dictionaries, directories or encyclopædias and the like. The lists should thus be of real value to specialist, as well as to public, librarians, in dealing with the difficult problem of book selection, particularly in fields of which the librarian himself has no special knowledge.

\section{Maimonides}

Dr. M. GASTER delivered a lecture on "Maimonides and his Works" at a meeting on November 14 of the Royal Asiatic Society in conjunction with the Society for Old Testament Study. He said that Maimonides was a man of strong faith which deeply influenced his activity. Fully conversant with the Hebrew and Arabic literature of the time, he displayed a threefold activity. First, his legal activity consisted in compiling for the first time a comprehensive code of laws which has remained the basis of Judaism to this very day, and prevented it from splitting up into sects. Secondly, his medical activity was intended to prove, besides furthering and stimulating medical research, that there is no incompatibility between science and faith ; indeed, that they assist one another. Thirdly, his philosophical activity was intended to reconcile the tenets of faith with philosophic speculation. $\mathrm{He}$ endeavoured to answer some of the fundamental problems of human life, such as the existence of God, the problem of creation, the relation between God and man, revelation, sin and evil, punishment and reward, and immortality. With slight modification, the answers which he gave retain their value even at the present time.

\section{Sir John McLennan, K.B.E., F.R.S.}

IN the obituary notice of Sir John McLennan published in Nature of October 19 (p. 633), it was stated that he went from Toronto to Cambridge with an 1851 Exhibition Scholarship. Prof. A. S. Eve now informs us that this statement is not correct. Dr. E. F. Burton, who succeeded Sir john at Toronto, has written : "Although most of the men who were at the Cavendish with Dr. McLennan held 1851 Exhibition Scholarships, he did not have one himself. As a matter of fact, he resigned his position at Toronto in order to go abroad entirely at his own expense. It was in the nature of a gamble for him at that time as his resources were very meagre, but he realised that this was the only possible course to take if he wanted to work in what was then modern physics. He was undoubtedly moved to do this by the meeting of the British Association for the Advancement of Science in Toronto in 1897, as it was just after this that he went to England." 